\title{
SENSE OF POWER PADA MAHASISWA DITINJAU DARI POLA ASUH IBU
}

\author{
Alice Whita Savira \\ Universitas Sanata Dharma \\ alicewhitasavira@usd.ac.id, alicewhitasavira@gmail.com
}

\begin{abstract}
Abstrak: Penelitian ini bertujuan untuk mengetahui perbedaan sense of power mahasiswa ditinjau dari pola asuh ibu. Hipotesis dalam penelitian ini adalah ada perbedaan sense of power mahasiswa ditinjau dari pola asuh ibu. Dimana sense of power mahasiswa paling tinggi adalah mahasiswa yang diasuh dengan pola asuh otoritatif dan yang memiiki sense of power paling rendah adalah mahasiswa yang diasuh dengan pola asuh otoritarian. Subjek dalam penelitian ini adalah 82 mahasiswa yang diambil dengan teknik pengambilan sampel accidental. Alat pengumpulan data menggunakan skala sense of power Anderson (2012) dan skala parental authority questionnaire (PAQ) (Buri, 1991), Uji coba alat ukur telah dilakukan dan menunjukkan reliabilitas skala sense of power 0,827 . Skala PAQ dengan reliabilitas 0,773 untuk skala ibu permisif, 0,748 untuk skala pola asuh ibu otoritarian, dan 0,855 untuk skala pola asuh ibu otoritatif. Teknik analisis yang dilakukan adalah menggunakan one way anova-games dowell. Uji hipotesis menunjukkan bahwa ada perbedaan yang signifikan pada sense of power mahasiswa ditinjau dari pola asuh ibu, dengan nilai sum of squares between groups $=873.181, \mathrm{p}$ $=0,000(\mathrm{p}<0,05)$. Perbedaan ini khususnya pada mahasiswa yang diasuh dengan pola asuh otoritarian dan pola asuh otoritatif. Mahasiswa yang diasuh dengan pola asuh otoritarian memiliki sense of power yang paling rendah dibandingkan dengan mahasiswa yang diasuh dengan pola asuh otoritatif dan perimisif. Analisis tambahan juga dilakukan untuk melihat sense of power berdasarkan gender mahasiswa.
\end{abstract}

Kata kunci : sense of power, pola asuh ibu, gender

Abstract: This study aimed to determine differences in students' sense of power in terms of parenting. The hypothesis in this study was there would be differences in students' sense of power in terms of parenting: the highest student's sense of power is students who are raised with authoritative parenting and those who have the lowest sense of power are students who are raised with authoritarian parenting. Subjects in this study were 82 students taken by accidental sampling technique. The data collection tools were Anderson's sense of power scale (2012) and the parental authority questionnaire (PAQ) scale (Buri, 1991). The measuring scale has been tested. The reliability score of the sense of power was 0.827. PAQ scale's reliability score were 0.773 for the permissive mother scale, 0.748 for the authoritarian mother scale, and 0.855 for the authoritative mother scale. One way anova dowell games was used as the analysis tool. Hypothesis testing showed that there were significant differences in students' sense of power in terms of maternal parenting, with a sum of squares between groups $=873,181, p=$ 0,000 ( $p$ <.05). This difference happened especially for students who are raised with authoritarian parenting and authoritative parenting. Students who are raised with authoritarian parenting had the lowest sense of power compared to students who are raised with authoritative and perimisive parenting. Additional analysis was also conducted to see the sense of power based on the gender of students.

Keywords: sense of power, parenting, gender 


\section{PENDAHULUAN}

Mahasiswa yang erat berhubungan dengan kehidupan kuliah dan organisasi kampus, dituntut untuk mencapai target perkuliahan ataupun di organisasi. Dalam rangka mencapai target tersebut, mahasiswa akan mengalami proses penyelesaian masalah, pengambilan risiko, dan pembuatan keputusan baik dalam tugastugas secara kelompok kuliah maupun di dalam organisasi. Dalam penyelesaian tugas kelompok maupun tugas dalam organisasi, seringkali individu perlu menerapkan praktik kepemimpinan dimana ia diharuskan mempengaruhi orang lain agar target yang diharapkannya dapat dicapai secara efektif. Terjadi atau tidaknya proses mempengaruhi orang lain sangat bergantung dari persepsi individu dalam melihat kemampuannya mempengaruhi orang lain. Dalam konstruk psikologis hal ini disebut dengan sense of power (Anderson, 2012).

Sementara itu, terdapat fenomena yang cukup umum terjadi di kelas yaitu ada mahasiswa yang melihat setiap tantangan sebagai kesempatan, mau mengambil peran sebagai pemimpin yang mengorganisasikan tugas, lebih antusias, dan beroientasi pada pencapaian target yang diinginkan. Ada pula mahasiswa yang justru melihat tantangan dengan penuh kecemasan karena penuh ketidakpastian, inferior, tidak mau menjadi pemimpin, malu-malu, mudah takut, dan melihat tantangan sebagai sebuah ancaman ataupun hukuman (Keltner, 2003). Karakteristik mahasiswa yang bertolakbelakang tersebut merupakan karakteristik dari individu yang memiliki sense of power yang tinggi dan individu yang memiliki sense of power yang rendah. Realita tersebut berdampak pada isu bahwa tidak semua mahasiswa mampu mempengaruhi orang lain dalam rangka penyelesaian masalah, pengambilan risiko, dan pembuatan keputusan dalam tugas kelompok ataupun organisasi secara efektif.
Perbedaan sense of power pada mahasiswa tersebut disebabkan oleh konsep diri yang berbeda. Konsep diri merupakan persepsi seseorang mengenai dirinya, terbentuk karena pengalaman dan interaksi dengan lingkungan (termasuk hubungan dengan orang lain). Konsep diri akan mempengaruhi tingkah laku seseorang di masa depan. Combs dan Syngg (dalam Fitts, 1971) menekankan pentingnya peran keluarga dalam pembentukan konsep diri karena keluarga tempat pertama individu berinteraksi. Peran keluarga dapat berupa pola asuh orangtua dimana dalam konteks budaya Indonesia, sering kali pola asuh diasosiakan dengan pola asuh ibu. Pola asuh ibu terbagi menjadi tiga model yaitu otoritarian, otoritatif, dan permisif Baumrind (dalam Buri, 1991).

Berdasarkan ulasan diatas, maka penelitian ini bertujuan untuk melihat perbedaan sense of power mahasiswa ditinjau dari pola asuh ibu. Hal ini akan menambah luas kajian terkait sense of power yang masih terbatas, terutama yang berkaitan dengan determinan yang mempengaruhi sense of power seseorang. Analisis tambahan juga akan dilakukan dalam penelitian ini untuk melihat pengaruh gender terhadap sense of power mahasiswa.

\section{Sense of power}

Sebelum memahami apa yang dimaksud dengan sense of power, kita perlu melihat terlebih dahulu apa yang dimaksud dengan power. Power adalah kapasitas untuk mempengaruhi orang lain. (Anderson et al, 2012). Manifestasi dari power setidaknnya ada empat yaitu adalah kemampuan untuk memegang kendali atas keputusan bersama (Grat-Little \& Burks, 1983 dalam Anderson et al, 2012) mempengaruhi perilaku orang lain (Goldhamer \& Shils, 1939, dalam Anderson et al 2012), dan dapat memuaskan kebutuhan orang lain meskipun keinginan tersebut berseberangan dengan orang lain (Ng 1980 dalam Anderson et al, 2012), 
membangun kapasitas internal (Keltner et al., 2003). Dengan demikian, secara prinsip orang tidak harus menggunakan kekuasaannya untuk dipertimbangkan sebagai sosok yang powerful. Seseorang tidak harus selalu memberikan perintah agar dipertimbangkan sebagai sosok yang powerful, tetapi ia harus memiliki kemampuan untuk memodifikasi perilaku orang lain (Anderson et al, 2012).

Power dalam konteks psikologis yang diukur secara individual disebut dengan personal sense of power (Anderson et al., 2012; Galinsky, Gruenfeld, \& Magee, 2003). Sense of power ini merupakan konstruk yang lebih mendasar. Sense of power diartikan sebagai persepsi individu dalam melihat kemampuannya mempengaruhi orang lain (Anderson, 2012). Ada dua hal yang menjadi perhatian dalam teori personal sense of power. Pertama, sense of power individu berbeda dari power dalam konteks sosiostruktural. Terkadang sense of power seseorang berkaitan dengan posisi, otoritas atau status di mata orang lain dan terkadang tidak. Sense of power bukan sekedar kemampuan mengontrol pekerjaan atau masalah otonomi tugas, bukan pula sekedar kemampuannya untuk mempengaruhi perilaku kerja dan hasilnya. Konstruk ini melekat pada hubungan sosial dan mempengaruhi sikap, perilaku, dan hasilnya, serta dapat dipahami hanya di dalam hubungan dengan orang lain (Anderson et al, 2012). Kedua, individu yang percaya bahwa power yang mereka miliki dapat mempengaruhi orang lain melebihi efek dari posisi sosiostruktural yang mereka miliki. Persepsi bahwa dirinya mampu mempengaruhi orang lain tersebut akan menentukan terjadi/tidaknya proses mempengaruhi bawahan (Anderson et al, 2012). Mereka yang mempersepsikan diri lebih powerful berperilaku lebih efektif yang akan meningkatkan power yang seseungguhnya (Anderson et al, 2012).

Sense of power mempengaruhi emosi, kognisi, ataupun perilaku seseorang.
Apabila seseorang merasa mampu mempengaruhi orang lain, maka akan timbul perasaan yang positif, dominasi, asertif, dan peran sebagai pemimpin, dan memiliki orientasi pada penghargaan (reward) (Anderson et al 2001 dalam Keltner et al., 2003). Sedangkan ketika seseorang merasa tidak memiliki kemampuan mempengaruhi orang lain maka akan timbul rasa malu, takut, rasa bersalah sedih, dan melihat sesuatu sebagai ancaman (Anderson et al 2001 dalam Keltner et al., 2003). Keltner et al (2003) mengemukakan bahwa hal ini mengganggu perfomansi kognitif dimana seseorang akan meletakkan fokus perhatian pada pendapat orang lain tentang dirinya yang berdampak pada pola pikir yang rumit .

Dalam konteks yang lebih luas, dengan memiliki sense of power maka seseorang akan dapat mengontrol perilaku orang lain yang berdampak pada hasil (Tost, 2015). Sense of power dapat membantu seseorang untuk lebih aktif dalam berkomunikasi, menyelesaikan konflik, membuat orang percaya diri, membuat keputusan secara strategis, dan mengambil risiko yang pada akhirnya berdampak pada hasil kerja (Morisson et al., 2014; Anderson \& Galinsky,2006)

\section{Pola Asuh Ibu}

Baumrind (1971) berpendapat bahwa pada prinsipnya pola asuh merupakan kontrol orang tua, (termasuk di dalamnya adalah ibu), dalam rangka membimbing dan mendampingi anak-anaknya guna melaksanakan tugas perkembangan. Bumrind (1971), menyatakan ada 3 model pengasuhan yaitu permisif, otoritarian, dan otoritatif.

Ibu permisif tidak merasa dirinya berkuasa dan menggunakan kekuasaannya dalam keluarga untuk mencapai tujuan pengasuhan anak. Secara umum, ibu tidak mengontrol dan cenderung tidak memberi hukuman kepada anaknya. Ibu memiliki sedikit tuntutan dan perintah terhadap 
anaknya. Ibu memberikan kebebasan penuh pada anak untuk mengelola aktivitasanya dan membuat keputusan bagi dirinya sendiri walaupun belum sesuai dengan tahap perkembangan anak (Buri, 1991;Santrock , 2011).

Ibu otoritarian berkebalikannya, cenderung mengarahkan secara langsung dan memiliki aturan yang ketat dimana aturan tersebut tidak boleh dipertanyakan ataupun didiskusikan. Mereka menggunakan hukuman untuk mengontrol perilaku anaknya. Hubungan antara orangtua sangat jauh dan lebih tidak hangat dibandingkan model pengasuhan yang lain (Buri, 1991). Komunikasi diantara orangtua dan anak relatif minim.. Pola asuh ini lebih menekankan pada kebutuhan orang tua, sedangkan ekspresi diri dan kemandirian anak ditekan dan dihalangi. Anak yang dibesarkan dengan pola pengasuhan seperti ini biasanya lebih pasif, tidak mandiri, kurang terampil bersosialisasi, penuh dengan konflik, kurang percaya diri dankurang memiliki rasa ingin tahu (Santrock,2011).

Ibu otoritatif berada ditengah-tengah antara dua model ekstrim di atas. Ibu mengasuh anaknya dengan menetapkan standar perilaku bagi anak namun juga responsif terhadap kebutuhan anak. Ibu mengarahkan aktivitas anak secara rasional, menerima perilaku asertif anak, menghargai minat anak, menghargai keputusan anak, dan memberi kesempatan pada anak untuk mendiskusikan mengenai aturan, norma, dan nilai-nilai (Santrock,2011). Pada intinya, ibu akan memberikan perintah yang jelas dan tetap memegang kendali atas anak, tetapi penanaman kedisiplinan dimoderasi dengan kehangatan, alasan, fleksibilitas, dan diskusi (Buri, 1991). Anak-anak dengan pola asuh ototritatif cenderung mandiri, tanggung jawab dan berorientasi pada tujuan, sedangkan anak-anak dengan pola asuh permisif ataupun otoritarian mengalamai kekurangan dalam area ini (Buri, 1991).
Dinamika Perbedaan Pola Asuh Ibu terhadap Sense of power Mahasiswa

Persepsi seseorang mengenai dirinya merupakan bagian dari konsep diri yang secara definisi diartikan sebagai kumpulan keyakinan dan persepsi diri mengenai diri sendiri (Baron dan Byrne, 2005). Demikian juga dengan persepsi seorang mahasiswa mengenai kemampuan seseorang dalam mempengaruhi orang lain atau secara konstruk psikologis disebut dengan sense of power. Konsep diri terbentuk dari hasil belajar individu ketika berinteraksi dengan orang lain termasuk di dalamnya orangtua. Hal ini sejalan dengan Sulivan (dalam Fitts, 1971) mengemukakan bahwa seseorang akan menilai dan memandang dirinya sendiri melalui penilaian ataupun perlakuan orang lain terhadap dirinya. Dengan demikian, perbedaan pola asuh orangtua akan mempengaruhi konsep diri mengenai sense of power seseorang.

Orangtua khususnya ibu merupakan orang pertama yang melakukan interaksi dengan anaknya. Ibu dengan pola asuh otoritarian menunjukkan kekuasaan penuh di dalam keluarga dan tidak memberi kesempatan pada anak untuk menyatakan pendapat ataupun mendiskusikan suatu hal. Anak yang diasuh dengan pola asuh otoritarian tidak memiliki hak bertanya terhadap aturan orangtua dan hak berpendapat. Ia akan belajar selalu menerima keputusan yang dibuat oleh orangtuanya tanpa pernah mencoba meyakinkan orangtua terkait pendapat pribadinya. Perlakuan ibu terhadap anak tersebut berkontribusi mengembangkan konsep diri yang negatif yaitu bahwa diri anak tidak mampu mempengaruhi orangtua. Anderson (2012) menemukan bahwa sense of power tergantung dari konteks hubungan seseorang dengan orang lain namun konsisten di antara berbagai hubungan. Sebagai contoh persepsi seseorang terhadap kemampuannya mempengaruhi teman berbeda dengan persepsi mempengaruhi 
pimpinan, namun persepsi bahwa ia mampu mempengaruhi ini cukup konsisten. Dengan demikian, individu yang mengevaluasi dirinya sebagai sosok yang tidak memiliki kemampuan mempengaruhi di keluarga, akan memiliki persepsi yang sama mengenai kemampuan mempengaruhi orang lain dalam hubungannya dengan siapapun. Hal tersebut termasuk ketika individu menjadi mahasiswa dan harus berhubungan dengan teman, bawahan ataupun atasan di perkuliahan atau organisasi kampus. Ia akan merasa pendapatnya tidak pernah didengarkan, ideidenya diabaikan, keinginannya tidak pernah dipertimbangkan, tidak memiliki kemampuan untuk membuat sesuatu terjadi, dan merasa tidak akan mendapat hal yang diinginkan atau yang menjadi tujuannya (Anderson, 2012).

Pola asuh otoritatif dan perimisif relatif sama dalam menerima perilaku asertif anak, menghargai minat anak, dan menghargai keputusan anak. Dalam pola asuh otoritatif, ibu mengarahkan aktivitas anak secara rasional. Ibu menetapkan aturan, norma, dan nilai-nilai yang harus tertanam dalam diri anak namun juga memberi kesempatan pada anak untuk mendiskusikan mengenai aturan, norma, dan nilai-nilai. Anak dengan pola asuh otoritatif akan belajar untuk mendiskusi pendapat dan keinginannya kepada orangtuanya. Ibu tidak kaku dalam menerapkan aturannya dan selama pendapat anaknya masih sesuai dengan aturan/norma/nilai yang ingin diinternalisasi pada anaknya, orang tua akan menyetujui (Buri, 1991;Santrock 2011). Proses belajar yang terus menerus mengenai hal ini akan membentuk konsep diri anak bahwa ia mampu mempengaruhi orang lain (Anderson,2012). Konsep ini pun akan ia bawa sampai menjadi mahasiswa ketika berhubungan dengan teman kuliah ataupun organisasi.

Dalam pola asuh permisif, anak diberi kewenangan penuh tanpa diberi aturan yang jelas dalam pengelolaan aktivitas diri dan berperilaku. Ia terbiasa mendominasi dalam keluarga terkait keputusan-keputusan untuk hidupnya namun ia kurang memiliki pedoman mana yang seharusnya dilakukan dan tidak, mana perilaku yang diberi penguatan ataupun dilemahkan oleh orangtua. Anak tidak pernah belajar untuk mengontrol perilaku dan selalu berharap untuk mendapatkan apa yang mereka minta. Selain itu, anak akan jarang untuk belajar menghargai orang lain, tidak dapat memahami sudut pandang orang lain, tidak mau mengalah, dan kesulitan dalam hubungan pertemanan merupakan beberapa potensi resiko dalam perkembangannya (Santrock,2011).

Kebiasaan yang terbentuk didalam keluarga tersebut akan mengarahkannya pada suatu persepsi bahwa dirinya mampu membuat orang lain menuruti apa yang diinginkannya (sense of power). Namun sense of power ini tidak lebih tinggi dibandingkan dengan mahasiswa dengan pola asuh otoritatif karena anak dengan pola asuh permisif cenderung mengalami kesulitan dalam pertemanan akibat kontrol diri yang kurang. Dengan pengalaman pertemanan yang terjadi sebelumnya, akan berkontribusi pada rasa ragu terkait persepsi mengenai kemampuan mempengaruhinya tersebut.

Berdasarkan teori di atas, maka peneliti mengajukan hipotesis mayor bahwa ada perbedaan tingkat sense of power mahasiswa ditinjau dari pola asuh ibu. Hipotesis minor pertama adalah bahwa sense of power mahasiswa dengan pola asuh ibu otoritarian lebih rendah dibandingkan dengan sense of power mahasiswa dengan pola asuh permisif dan otoritatif. Hipotesis minor kedua adalah bahwa tidak ada perbedaan yang signifikan antara tingkat sense of power mahasiswa dengan pola asuh ibu permisif dan pola asuh otoritatif. 


\section{METODE}

Sampel penelitian ini adalah 82 mahasiswa yang diambil dengan teknik pengambilan sampel accidental sampling. Accidental sampling adalah teknik pengambilan sampel dimana sampel secara kebetulan/incidental bertemu dengan peneliti, dan dipandang cocok sebagai sumber data (Sugiyono, 2011). Skala pola asuh orangtua diadaptasi dari Buri (1991) yang mengukur purwarupa pola asuh orangtua yaitu permisif, otoritarian, dan otoritatif. Skala sense of power diadaptasi dari Anderson et al (2012) Skala sense of power dan pola asuh orangtua diujicobakan kepada 60 subjek. Uji hipotesis menggunakan metode statistika one way anova.

\section{HASIL}

Berdasarkan hasil uji coba skala pada 60 subjek, didapatkan nilai reliabilitas koefisien Cronbach alpha skala pola asuh ibu permisif 0,773 , pola asuh ibu otoritarian 0,748 , dan pola asuh ibu otoritatif 0,885 . Sedangkan skala sense of power memiliki koefisien Cronbach alpha 0,827. Hal ini menunjukkan bahwa semua alat ukur tersebut dapat dipercaya. Alpha $\geq 0.7$ dianggap baik (Nunally, 1978).

Distribusi data penelitian menggunakan penghitungan mean hipotetik, menunjukkan bahwa dari 82 subjek penelitian, subjek yang tergolong memiliki sense of power yang tinggi sebanyak 52 responden $(63,4 \%)$, sedang sebanyak 26 $(31,70 \%)$ responden, dan rendah sebanyak 4 responden $(4,88 \%)$. Selanjutnya, dari 82 subjek, sebanyak $16(19,5 \%)$ mempersepsi ibu mereka memiliki kecenderungan pola asuh permisif, sebanyak $17(20,7 \%)$ pola asuh otoritarian, dan sebanyak $49(59,8 \%)$ memiliki kecenderungan pola asuh otoritatif.

Sebelum dilakukan pengujian hipotesis, perlu dilakukan uji asumsi normalitas dan homogenitas pada data. Karena sampel penelitian ini lebih dari 50, maka uji normalitas menggunakan nilai
Kolmogorov-smirnov. Semua data normal dimana data pola asuh permisif dengan sense of power adalah sebesar 0,120, otoritarian dengan sense of power sebesar 0,138 , dan otoritatif dengan sense of power adalah sebesar 0,102 ( $>0,05)$. Namun demikian data sense of power dan pola asuh tersebut tidak homogen dengan nilai levene statistic $=11,139, \mathrm{p}=0,000 \quad(\mathrm{p}>0,05)$. Berdasarkan uji asumsi yang telah dilakukan tersebut, maka uji hipotesis dilakukan dengan one way anova dengan post hoc games Howell.

Hasil uji hipotesis menunjukkan bahwa nilai sum of squares between groups $=873.181, \mathrm{p}=0,000(\mathrm{p}<0,05)$, sehingga dapat disimpulkan bahwa rata-rata sense of power dari 3 jenis pola asuh itu berbeda secara signifikan. Rata-rata sense of power individu dengan pola asuh ibu permisif adalah sebesar 39,3, dengan pola asuh otoritarian sebesar 33,11, dan dengan pola asuh otoritatif sebesar 41,40. Dengan demikian, maka secara deskriptif dapat disimpulkan bahwa rata-rata sense of power individu yang paling tinggi adalah individu dengan pola asuh otoritatif, sedangkan ratarata sense of power yang paling rendah adalah individu dengan pola asuh otoritarian.

Uji post hoc games dowel membandingkan rata-rata sense of power pada individu dengan 3 jenis pola asuh. Hasil menunjukkan bahwa sense of power individu dengan pola asuh ibu otoritarian dan sense of power individu dengan pola asuh ibu otoritatif berbeda secara signifikan, dengan perbedaan rata-rata $-8,29, \mathrm{p}=0,15$ $(p<0,05)$. Sedangkan sense of power individu dengan pola asuh ibu permisif dan sense of power individu dengan pola asuh otoritatif memiliki nilai perbedaan rata-rata $1,47 \mathrm{p}=0,575 \quad(\mathrm{p}<0,05)$ atau tidak signifikan. Secara singkat, dapat disimpulkan bahwa hanya rata-rata sense of power individu dengan pola asuh ibu otoritarian dan otoritatif saja yang berbeda secara signifikan. 
Analisis tambahan juga dilakukan dalam penelitian ini. Uji independent sample $t$ test juga dilakukan untuk melihat perbedaan sense of power mahasiswa pria dan wanita. Data penelitian menunjukkan bahwa subjek penelitian terbagi atas 17 lakilaki $(20,73 \%)$ dan 65 perempuan $(79,27 \%)$. Levene's test menunjukkn Nilai $F=1,246$, $\mathrm{p}=0,268$. Karena $\mathrm{p}>0,05$ maka dapat dikatakan tidak ada perbedaan varians antara sense of power laki-laki dan perempuan. Nilai $\mathrm{t}=-0,961, \mathrm{p}=0,340$ $(p<0,05)$. Hal ini menunjukkan bahwa tidak ada perbedaan antara sense of power lakilaki dan perempuan. Rata-rata sense of power laki-laki adalah 37,88 dan rata-rata sense of power perempuan adalah sebesar 39,80

\section{PEMBAHASAN}

Hasil penelitian menunjukkan bahwa ada perbedaan tingkat sense of power mahasiswa yang signifikan ditinjau dari pola asuh ibu. Tingkat sense of power yang paling tinggi adalah mahasiswa yang diasuh dengan pola asuh ibu otoritatif, di bawahnya adalah mahasiswa yang diasuh dengan pola asuh ibu permisif, dan yang memiliki tingkat sense of power yang paling rendah adalah mahasiswa yang diasuh dengan pola asuh ibu otoritarian. Dengan demikian hipotesis yang diajukan diterima.

Pola asuh orangtua diartikan sebagai serangkaian aksi dan interaksi yang dilakukan oleh orangtua dalam membantu perkembangan anak baik fisik, psikologis, maupun sosial. Dalam konteks budaya Indonesia, sering kali peran pengasuhan lebih diasosiasikan pada ibu. Melalui pola asuh, nilai-nilai dalam keluarga diajarkan termasuk didalamnya hal kebebasan berpendapat dan kepercayaan untuk mengambil keputusan secara pribadi. Sulivan (dalam Fitts, 1971) mengemukakan bahwa seorang anak akan menilai dan memandang dirinya sendiri melalui penilaian ataupun perlakuan orang lain terhadap dirinya. Dengan demikian perlakuan ibu terhadap anak yang telah menjadi mahasiswa pun berkontribusi mengembangkan konsep diri yang negatif ataupun konsep diri yang positif.

Baumrind membagi pola asuh menjadi tiga yaitu otoritarian, otoritatif, dan permisif (Buri, 1991). Mahasiswa dengan pola asuh ibu otoritatif sedari kecil akan belajar untuk mendiskusi pendapat dan keinginannya kepada ibunya. Ibu pun tidak kaku dalam menerapkan aturannya dan selama pendapat anaknya masih sesuai dengan aturan/norma/nilai yang ingin diinternalisasi pada anaknya, ibu akan menyetujui. Proses belajar yang terus menerus mengenai hal ini akan membentuk konsep diri positif dimana seorang anak merasa mampu mempengaruhi orang lain. Montana, 2001 (dalam Respati et al 2006) memberikan ciri-ciri tingkah laku seseorang yang mempunyai konsep diri positif diantaranya ada keinginan menjadi pemimpin, mau mengambil risiko, dan bersikap mandiri, percaya bahwa dirinya mempunyai kontrol pada hidup mereka, merasa mampu menangani/mempengaruhi lingkungan. Disamping itu, seseorang yang diasuh menggunakan pola asuh otoritatif memang cenderung memiliki kompetensi sosial yang baik (Santrock,2011). Dalam berhubungan sosial, tentu ada proses mempengaruhi orang lain di dalam kelompok dalam rangka mencapai sebuah keputusan.

Hal ini diperkuat oleh beberapa penelitian menunjukkan bahwa. pola asuh otoritatif berhubungan positif dengan dimensi kepribadian extraversion, conscientiousness, dan openness to experience dimana dimensi kepribadian ini memiliki hubungan positif dengan sense of power seseorang (Sravanthi, 2007 \& Kilonzo, 2017). Seseorang yang diasuh dengan pola asuh otoritatif akan berkontribusi membentuk dan mengembangkan dimensi kepribadian ekstraversion, conscientiousness, dan openness to experience. Semakin seseorang 
didominasi oleh kepribadian ekstraversi dimana hal ini dicirikan sebagai sosok yang asertif, tegas, dan antusias (Ramdhani, 2012), semakin tinggi sense of powernya persepsinya bahwa ia mampu mempengaruhi orang lain (Anderson e $t$ al, 2012). Demikian juga dengan dimensi kepribadian conscientiousness yang dicirikan sebagai sosok yang hadir tepat waktu dan tampil berprestasi , dan dimensi kepribadian openness to experience yang dicirikan sebagai sosok yang terbuka terhadap wawasan (Ramdhani, 2012). Kedua dimensi kepribadian ini, yang terbentuk karena pola asuh otoritatif juga memiliki asosiasi positif dengan sense of power seseorang (Anderson e t al, 2012; Savitha \& Venkatachalam, 2016; Dordi \& Pol, 2018). Bahwa semakin seseorang didominasi oleh dimensi kepribadian conscientiousness dan openness to experience semakin tinggi sense of powernya. Hal ini menjadi temuan baru bahwa sense of power tidak berhenti ditentukan oleh dimensi kepribadian seperti level ekstraversi saja, namun ada yang lebih mendasar yaitu salah satu faktor yang membentuk kepribadian seseorang yaitu pola asuh orangtua khususnya ibu.

Berbeda dengan pola asuh otoritatif, pola asuh otoritarian yang cenderung feodal akan mengembangkan sikap anak sebagai seorang pengikut dan tidak mandiri dalam mengambil keputusan (Santrock, 2011). Hal ini dikarenakan ibu tidak menyukai apabila anaknya membantah, memprotes apalagi mengkritik aturan yang telah dibuatnya, sehingga dari kecil anak tidak memiliki kesempatan supaya bisa memberikan pendapat atau mengemukakan ide, gagasan dan pemikirannya bahkan inisitif yang dimiliki anak, yang pada akhirnya membuat anak cenderung tumbah menjadi pribadi yang lebih senang menjadi pengikut dan terbiasa dipengaruhi oleh orang lain. Anak akan dihukum apabila melakukan hal-hal yang tidak dikehendaki oleh orangtuanya. Proses belajar yang terus menerus mengenai hal ini di dalam keluarga akan membentuk konsep diri negatif dimana anak yang telah menjadi mahasiswa pun merasa tidak mampu mempengaruhi orang lain. Seseorang dengan konsep diri negatif menunjukkan ciri-ciri menghindari kepemimpinan, tidak mau mengambil risiko, mereka akan berbuat apa saja untuk menyesuaikan diri dan menyenangkan orang lain, dan merasa inferior (Burns ,1982 \& Montana, 2001 dalam Respati et al 2006). Hal ini didukung oleh Santrock (2011), bahwa anak yang diasuh dengan pola asuh otoritarian cenderung penakut, tidak percaya diri (cemas ketika harus membandingkan sesuatu dengan orang lain), dan memiliki ketrampilan komunikasi yang buruk. Hal ini karena anak tidak pernah diajari sebagai agen aktif yang akan menentukan tindakan di masa depan. Sebaliknya, anak cenderung dituntut untuk selalu tunduk pada otoritas orangtua.

. Sedangkan dalam pola asuh permisif, anak diberi kewenangan penuh tanpa diberi aturan yang jelas dalam pengelolaan aktivitas diri dan berperilaku,dan toleransi orangtua. Ia terbiasa mendominasi dalam keluarga terkait keputusan-keputusan untuk hidupnya namun ia kurang memiliki pedoman mana yang seharusnya dilakukan dan tidak, mana perilaku yang diberi penguatan ataupun dilemahkan oleh orangtua. Anak tidak pernah belajar untuk mengontrol perilaku dan selalu berharap untuk mendapatkan apa yang mereka minta. Selain itu, anak akan jarang untuk belajar menghargai orang lain. tidak dapat memahami sudut pandang orang lain, tidak mau mengalah, dan kesulitan dalam hubungan pertemanan. Hal-hal tersebut beberapa potensi resiko dalam perkembangannya (Baumrind, 1971; Santrock,2011).

Kebiasaan yang terbentuk didalam keluarga tersebut akan mengarahkannya pada suatu persepsi bahwa dirinya mampu membuat orang lain menuruti apa yang diinginkannya (sense of power). Namun 
sense of power ini tidak lebih tinggi dibandingkan dengan mahasiswa dengan pola asuh otoritatif karena anak dengan pola asuh permisif cenderung mengalami kesulitan dalam pertemanan akibat kontrol diri yang kurang. Dengan pengalaman pertemanan yang terjadi sebelumnya, akan berkontribusi pada rasa ragu terkait persepsi mengenai kemampuannya tersebut.

Persepsi mahasiswa bahwa dia tidak memiliki kemampuan untuk mempengaruhi orang lain di keluarga, juga akan terimplementasi dalam hubungannya dengan mahasiswa di kampus. Hal ini akan tampak dalam bagaimana ia mengerjakan tugas kuliah ataupun organisasional secara tim. Anderson (2012) menemukan bahwa sense of power tergantung dari konteks hubungan seseorang dengan orang lain namun konsisten di antara berbagai hubungan. Sebagai contoh persepsi seseorang terhadap kemampuannya mempengaruhi teman berbeda dengan persepsi mempengaruhi pimpinan, namun persepsi bahwa ia mampu mempengaruhi ini cukup konsisten. Dengan demikian, individu yang mengevaluasi dirinya sebagai sosok yang tidak memiliki kemampuan mempengaruhi di keluarga, akan memiliki persepsi yang sama mengenai kemampuan mempengaruhi orang lain dalam hubungannya dengan siapapun. Hal tersebut termasuk ketika individu menjadi mahasiswa dan harus berhubungan dengan teman, bawahan ataupun atasan di organisasi kampus.

Analisis tambahan dilakukan dan hasil menunjukkan bahwa tidak ada perbedaan yang signifikan antara tingkat sense of power laki-laki dan perempuan. Hal ini bisa disebabkan perubahan pola pikir orangtua khususnya ibu terkait peran gender yang harus diemban laki-laki dan perempuan. Dimana perempuan juga memiliki kesempatan yang sama terkait akses, informasi, partisipasi dan lain sebagainya. Dalam pengasuhan, anak lakilaki dan perempuan diberi kesempatan yang sama dalam hal kewenangan, akses, dan partisiapasi terkait pengambilan keputusan (Puspitawati, 2012). Dengan demikian, anak laki-laki dan perempuan sama-sama memiliki persepsi yang sama terkait kemampuannya dalam mempengaruhi orang lain. Orangtua baik dengan tindakan maupun contoh, mempengaruhi perkembangan gender anak. Hal ini berbeda dengan pendapat bahwa budaya diberbagai belahan dunia, mencoba memberi peran yang berbeda antara laki-laki dan perempuan, seperti ibu mensosialisasikan kepada anak perempuannya untuk lebih patuh dan bertanggung jawab daripada anak laki-laki. Termasuk didalamnya melakukan pembatasan terhadap otonomi anak perempuan (Santrock, 2011; Puspitawati 2012).

\section{KESIMPULAN}

Hasil penelitian ini menunjukkan kesimpulan bahwa ada perbedaan tingkat sense of power individu ditinjau dari pola asuh ibu. Dimana sense of power individu dengan pola asuh otoritarian lebih rendah daripada individu dengan pola asuh otoritatif. Selain itu, sense of power antara laki-laki dan perempuan tidak berbeda. Hal ini dimungkinkan karena adanya perubahan ataupun perkembangan dari masa ke masa terkait peran gender yang diinternalisasikan orangtua kepada anak. Bahwa baik laki-laki maupun perempun diperkenankan memegang kendali atas pembentukan sebuah keputusan di dalam keluarga.

\section{SARAN}

Dalam rangka memperdalam penelitian mengenai sense of power dan melakukan generalisasi pada konteks yang lebih luas, maka subjek penelitian pada penelitian selanjutnya perlu diperbanyak dengan teknik pengambilan sampel random sampling. Subjek penelitian bisa saja dikenakan bukan pada mahasiswa namun pada karyawan ataupun orangtua. Selain itu masih perlu dikaji lebih dalam, mengenai 
faktor perbedaan budaya yang diasumsikan mempengaruhi sense of power seseorang. Penelitian selanjutnya juga dapat melibatkan pola asuh ayah agar kajian terhadap pengaruh pola asuh orang tua terhadap sense of power lebih komprehensif. Penelitian longitudinal juga dapat dilakukan, apakah individu yang memiliki sense of power yang tinggi karena dulunya diasuh menggunakan gaya pola asuh ibu otoritatif akan menggunakan pola asuh otoritatif juga ketika menjadi orangtua kelak.

\section{DAFTAR PUSTAKA}

Anderson, C., \& Galinsky, A. D. (2006). Power, optimism, and risk taking. European Journal of Social Psychology, 36, 511-536.

Anderson, C., John, O. P., \& Keltner, D. (2012). The Personal Sense of power. Journal of Personality, 80(2), 313-344.

Baumrind, D. (1971). Current Paterns of Parental Authority. Development Psychology Monograph, 4(1,Pt.2), 1103.

Baron, R.A., \& Byrne, D. 2005. Psikologi Sosial. Jilid II Edisi Kesepuluh (terjemahan Djuwita, R). Jakarta: Erlangga

Burns, R.B. (1982). Self-concept development and Education. London: Holt, Rinehart and Winston

Buri, J. R. (1991). Parental Authority Questionnaire. Journal of Personality Assessment, 57(1), 110-119.

Fitts, W.H (1971). The Self-concept and Psychopathology. Research Monograph No. 4. Nashville, TN : Dede Wallace Center.
Dordi, M. M., \& Pol, M. S. (2018). Relationship of Parenting Styles with Personality and Academic Motivation among Adolescents. International Journal of Indian Psychology, 6(1), 152-159.

Galinsky, A. D., Gruenfeld, D. H., \& Mage, J. C. (2003). From Power to Action. Journal of Personality and Social Psychology, 85(3), 453-466.

Keltner, D., Anderson, C., Gruenfeld, \& H, D. (2003). Power, Approach, and Inhibition. Psychological Review, 10(2), 265-284.

Kilonzo, P. M. (2017). The Impact of Parenting Styles on Personality Dimensions of Adolescents in Public Secondary Schools: A Case of Mombasa County, Kenya. International Journal of Education and Research, 5(7), 263-276.

Morrison, E. Q., See, K. E., \& Pan, C. (2014). An Approcah-Inhibition Model of Employee Silence : The Joint Effects of Personal Sense of power and Target Opennes. Personnel Psychology, 1-34.

Nunnally, J.C. (1978) Psychometric theory. 2nd Edition, McGraw-Hill, New York.

Ramdhani, N. (2012). Adaptasi Bahasa dan Budaya Inventori Big Fice. Jurnal Psikologi, 39(2), 189-207.

Respati, W. S., Yulianto, A., Widiana, \& Noryta. (2006). Perbedaan Konsep Diri Remaja Akhir yang Mempersepsi Pola Asuh Orangtua Otoritarian, Permissive, dan Autoritative. Jurnal Psikologi, 4(2), 119-138.

Santrock, J. W. (2011). Life-Span Development thirtheen edition. New York: McGraw-Hill. 
Savitha, K., \& Venkatachalam, J. (2016). Perceived Parenting Styles and Personality Factors-A Study. International Journal of Indian Psychology, 3(4), 21-33.

Sugiyono. 2011. Metode Penelitian Kuantitatif, Kualitatif dan R\&D. Bandung: Afabeta

Sravanthi, S. (2007). Effect of Parenting Styles on Personality Development of Adolescents. Acharya $\mathrm{Ng}$ Ranga Agricultural University, Rajendranagar, Hyderabad

Tost, L. P. (2015). When, why, and how do powerholders "feel the power'?Examining the links between structural and psychological power and reviving the connection between power and responsibility. Reserach in Organizational Behavior, 35, 29-56.

Puspitawati, H. 2012. Gender dan Keluarga: Konsep dan Realita di Indonesia. PT IPB Press. Bogor. 